http://journal.uinsgd.ac.id/index.php/biodjati

\title{
THE EFFECT OF THE PARTIAL SOLAR ECLIPSE ON BEHAVIOR OF THREE SPECIES OF ARDEIDAE IN RANCABAYAWAK BANDUNG
}

\author{
Johan Iskandar ${ }^{1 *}$, Budiawati Supangkat Iskandar ${ }^{2}$
}

Received : April 29, 2019

Accepted : September 29, 2020

DOI: 10.15575/biodjati.v5i2.4578

${ }^{1}$ Department of Biology, Faculty of Mathematics and Natural Sciences, Universitas Padjadjaran, J1. Raya Bandung-Sumedang $\mathrm{Km}$ 21, Jatinangor, Sumedang 45363, West Java, Indonesia. Tel./Fax.: +62-22-77912

${ }^{2}$ Department of Anthropology, Faculty of Social and Political Science, Universitas Padjadjaran, Jatinangor, Sumedang 45363, West Java, Indonesia. Fax. +62-22-77945.

e-mail:

*1johan.iskandar@unpad.ac.id

² budiawati.supangkat@unpad.ac.id

*Corresponding author

\begin{abstract}
The natural occurrence of solar eclipses can cause various impact on bird species. The purpose of this study was to examine the effect of the partial solar eclipses on changes in behavior of three species of Ardeidae in the Rancabayawak, Gedebage, Bandung, West Java. The research method used was qualitative which direct observation sampling technique was applied. The results of study showed that three bird species of Ardeidae namely Javan Pond-Heron (Ardeola speciosa Horsfield 1821), Buffalo Egret (Bubulcus ibis Linnaeus 1758, and small egrets (Egretta garzetta Linnaeus 1766) with total population 566 individuals were recorded in the resting and breeding place of bamboo trees and surrounding area of Rancabayawak during the partial solar eclipse. The behavior of these tree bird species, including sound of chicks, sunbathing, preening the feather, and flying of individual adults went out the resting and breeding place of bamboo trees observed tend to be normal before occurring the partial solar eclipse. During the partial solar eclipse, however, the sound of the chick stopped for a second. Some individual adult birds stopped involve in preening their feather. While, some adult individual birds were flying go back to the nest of bamboo trees that may be assumed it has already late afternoon due to dark of sun shine. Implication of this research have been considered to be very important for contributing the scientific knowledge on bird behavior changes caused by natural phenomena of the partial solar eclipse.
\end{abstract}

Keywords: Ardeidae, behavior, Rancabayawak, solar eclipse

\section{Citation}

Iskandar, J. \& Iskandar, B. S. (2020). The Effect of The Partial Solar Eclipse on Behaviour of Three Species of Ardeidae in Rancabayawak Bandung. Jurnal Biodjati, 5(2), 316-328.

\section{INTRODUCTION}

Various species of wildlife, including species of birds, their daily behavior in nature is influenced by local environmental factors, such as sunlight, weather, temperature, rainfall, habitat conditions and food availability in the ecosystem (Ritson et al., 2018). The species of wild birds that are active during the daylight (diurnal) are influenced by the conditions of the sun and air temperature. Generally in normal weather conditions, diurnal bird species have high activity in the morning. Then the activity of these species of bird decrease during the day, and their activities increase again in the afternoon. Based on direct full day observation in the field of Jatiluhur, Purwakarta, West Java, the maximum 


\section{JURNAL BIDDJATI}

http://journal.uinsgd.ac.id/index.php/biodjati

activity of diurnal birds is between 06.00 and 11.00 am with a temperature between $24^{\circ}$ and $34^{\circ}$ Celcius (Iskandar, 2017). Because in the morning the sun has not been blazing so various diurnal bird species are actively looking for food, likewise the afternoon sun is not blazing, those bird species are also actively looking for food. Thus, in addition to food, other factors, including temperature and humidity will also have indirect effects on bird activity and behavior. Therefore, some environmental factors, including food, temperature and humidity, light intensity, and wind speed can affect bird behavior in the ecosystem (Sodhi et al., 2011; Iskandar, 2017).

Natural solar eclipse events can be defined as times when the sun, moon, and earth are in parallel lines that cause the earth is engulfed in a shadow of the moon and blocks sunlight to enter the earth. As a result, earth became temporary dark (Lapan, 2016).

The solar eclipse can affect environmental conditions on earth, such as weather, air pressure, and the solar radiation intensity (Ardi et al., 2017; Nandyanto et al., 2017), and may change the behavior of animal species (Ritson et al., 2018), including birds (Nankinov et al., 2001; Ozbey et al., 2004). Solar eclipse events are very rare. On March 9,2016 , there was a total solar eclipse in some areas in Java and Bali, as well as a total solar eclipse outside Java, and a partial solar eclipse in Badung area.

The natural phenomenon of a solar eclipse can provide various impacts on the earth, including changes in the behavior of living things, such as the behavior of bird species. For example, some songbirds ceasing to sing during the solar eclipse (Wiantoro et al., 2019). In addition, Nankinov et al. (2001) mentioned that the birds reaction to solar eclipse strictly individuals. Birds of one and the same species, sex, and age may have different behavior. Thus, based on previous study revealed that birds behave abnormally during a solar eclipse (Tramer, 2000; Nankinov et al., 2001; Wiantoro et al., 2019)

The purpose of this study was to examine the effect of the partial solar eclipse on changes in the behavior of three species of Ardeidae in the Rancabayawak area, Gedebage, Bandung. These bird species were chosen for the study because they are predominantly found in the resting and breeding in the bamboo trees and are also easily observed during a partial solar eclipse. The Rancabayawak area, Gedebage is also considered to be the main habitat and remaining habitats for bird species of Ardeidae in the wetlands of Bandung City and its surroundings. Because of some wetland types, including paddy fields (sawah) in Bandung and surrounding area have been predominantly converted to other land uses, including houses (Kosasih, 2020). In addition, although some research on effect of the solar eclipse on bird species have been undertaken by some scholars, the special study on water birds, including species of Ardeidae has rarely undertaken (Wiantoro et al., 2019).

The three main aspects of this study were elaborated as follow assessing the existence of three bird species of Ardeidae in the Rancabayawak area; activities of three bird species of Ardeidae in the Rancabayawak area; and the effect of the partial solar eclipse on three bird species of Ardeidae in the Rancabayawak area. Because the solar eclipse events are very rare, this study has been considered to be very important for contributing the scientific knowledge on bird behavior changes caused by a solar eclipse in Indonesia. 


\section{JURNAL BIDDJATI}

http://journal.uinsgd.ac.id/index.php/biodjati

\section{MATERIALS AND METHODS}

This research was conducted in Rancabayawak, Cisaranten Kidul, Gedebage, East Bandung, West Java, on March 9, 2016 (Figure 1). Some materials used in this study were note book; field guide books for birds' identification; a binocular; photograph; and hand counter. The method used in this study was qualitative (Iskandar, 2017). Some techniques for collecting field data were direct observation with the help of binocular and identification of three bird species of Ardeidae directly, 'in-out' techniques of birds to the resting and breeding place of bamboo trees was used to count population, and observations of the bird behavior before, during and after the solar eclipse event. By employing in-out techniques of birds to the resting place, the population of birds can be counted, while observation of birds is considered to be an important technique for a careful search of bird behavior.

Observation of the three birds species of Ardeidae was carried out when the birds were resting and or nesting in bamboo trees (Bambusa vulagaris) in Rancabayawak hamlet and searching for food in the Rancabayawak paddy fields and surrounding areas. Birds identification referred to the field guide book of bird species in nature (MacKinnon et al., 1992; Bibby et al., 1992; Howes et al., 2003).

The population of three birds species of Ardeidae was estimated through direct counting before, during, and after the partial eclipse, particularly in the bamboo tree place and surrounding areas; while the total population estimation of three bird species of Ardeidae used the secondary data from the reports of Amdal $(2016,2017)$ and Team of Biology Unpad (2018). These bird population data were collected by direct count by using 'in-out' technique (Iskandar, 2017). The pop- ulation of three bird species Aredeidae was counted by all birds that came out from the resting place and /or nesting in bamboo trees. This observation was carried out in the morning from 05.15-07.00 am. Meanwhile, the estimation of the population of three bird species of Ardeidae that came back to the resting place and/or nesting was done in the afternoon at $04.00-06.00 \mathrm{pm}$. The total number of individuals entering and leaving the resting place and/or nesting is analyzed to estimate the population of three bird species of Ardeidae.

To find out the behavior change of three bird species of Ardeidae influenced by partial solar eclipse event was conducted by recording the behavior with direct observation (Pettingill, 1970). The behavior of three bird species of Ardeidae that perched, flew out and into the clumps of bamboo on the edge of the Rancabayawak hamlet were observed using binoculars from the top of the mosque towers adjacent to bamboo clumps that became nesting, resting and overnight three species of birds. Intensive observations of three species were carried out at the time of, during, and after the partial solar eclipse in one day. Some bird behavior variables, including chirping sounds, sunbathing, preening their feathers, flying away and returning to the nest in the bamboo tree, and perching silently on the bamboo trees are mainly observed (Burton, 1985). To find out the history of the existence of three species of Ardeidae in the Rancabayawak region and various disturbances, semi-structured interviews were conducted with competent informants, particularly local people of Rancabayawak (Iskandar, 2018).

\section{RESULTS AND DISCUSSION}

Based on the results of field research in the Rancabayawak area, Cisaranten Kidul, 


\section{JURNAL BIDDJATI}

http://journal.uinsgd.ac.id/index.php/biodjati

Gedebage Subdistrict, East Bandung, West Java three bird species of Ardeidae, namely Javan Pond-Heron (Ardeola speciosa Horsfield 1821), Cattle Egret (Bubulcus ibis Linnaeus 1758, and Small egret (Egretta garzetta Linnaeus 1766) were recorded. In terms of ecological history, based on interviews with informants, the local people of Rancabayawak hamlet, it revealed that three bird species of Ardeidae have been recorded for along time in the Rancabayawak paddy field, Gedebage, while their paddy fields are still a swamp, even before the construction of the Cinambo River flood control channel crossed the Rancabayawak in early 2002 .

Based on our primary and secondary data collected, today, even though the con- version of paddy fields into built-up land has become widespread, such as new housing in the Rancabayawak area, the three bird species of Ardeidae still survive in the area. During the day the three bird species of Ardeidae existed to search for resting and breeding place in bamboo trees, and looking for food in the rice fields of Rancabayawak or the surrounding areas, such as Buah Batu, Bojong Soang, Sapan, and Rancakekek (Department of Biology, 2018) (Figure 1). In the afternoon the three bird species of Ardeidae, returned to the resting place on bamboo trees (Bambusa vulgaris) on the edge of the Rancabayawak hamlet. In addition to rest place at night, the bamboo trees are also used for nesting places by three bird species of Ardeidae.

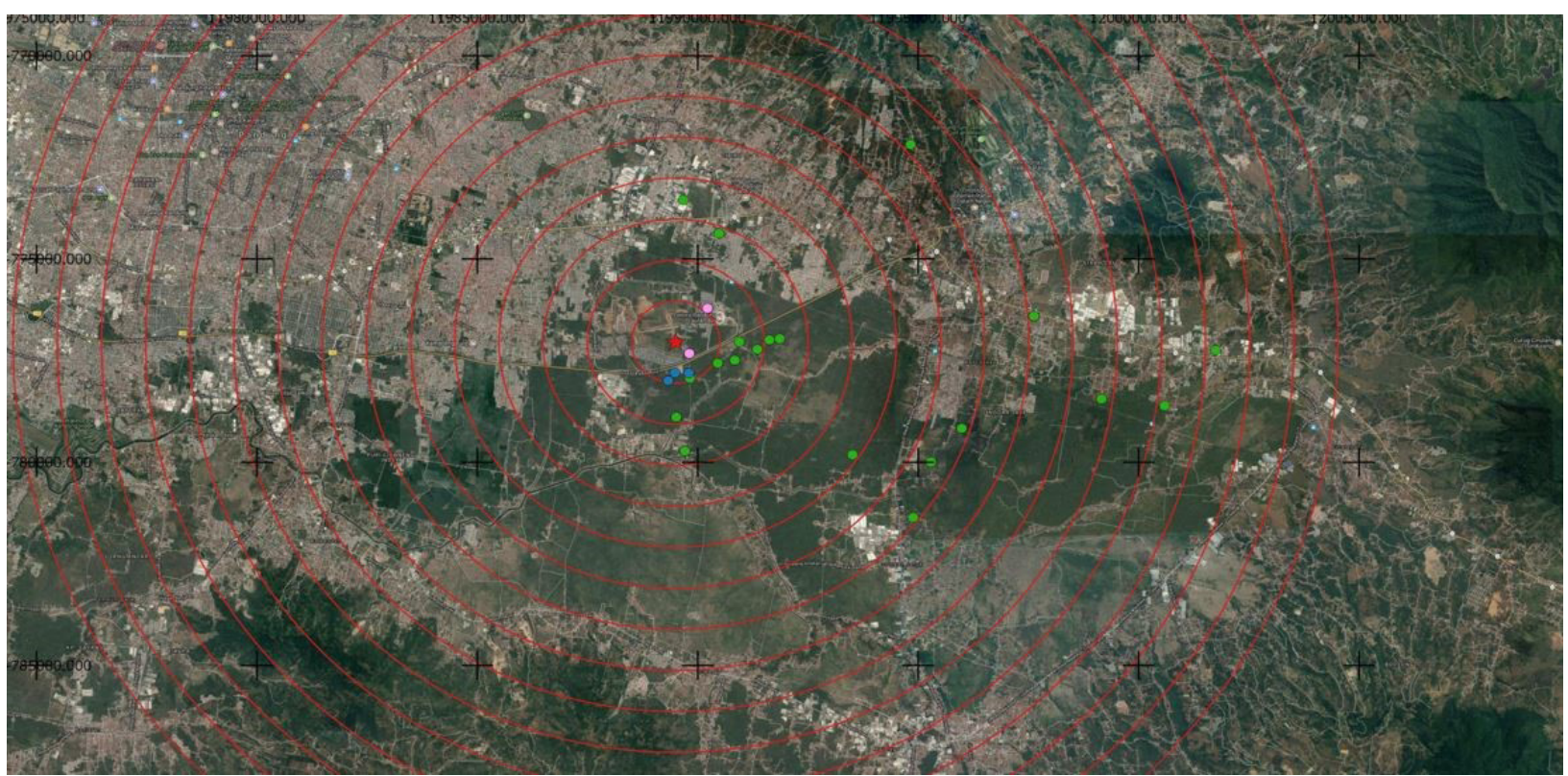

Figure 1. Distribution of the tree species in Rancabayawak and surrounding areas for looking food at the paddy fields. Red dot: the bamboo tress of Rancabayawak as resting and breeding place of Ardeidae; blue, green and brown dotes: the individuals of Ardeola speciosa, Bubulcus ibis, and Egretta garzeta were found in the paddy field of Rancabayawak, Buah Batu, Bojong Soang, Sapan, and Rancakekek, respectively. Source: Department of Biology, UNPAD (2018) 


\section{JURNAL BIDDJATI}

http://journal.uinsgd.ac.id/index.php/biodjati

The population of the three bird species of Ardeidae that usually rest, spend the night, and nest in bamboo clumps in Rancabayawak hamlet was estimated to be at least 2275 individuals in 2016, and a year later in 2017, a total of 1445-2412 individuals were recorded. Then, in 2018 the three bird species were recorded at 2152 individuals (Amdal, 2016; Amdal, 2017; Department of Biology, 2018). However, based on our study, direct count- ing for three species of Ardeidae by direct observation in the bamboo trees and surrounding area before, during, and after the partial eclipse (without counting the total population of going out in the morning and coming back in the afternoon) was documented a total 566 individuals, consisting of Bubulcus ibis 251 individuals, Ardeola speciose 190 individuals, and Egretta garzetta 125 individuals (Table 1).

Table 1. Estimation of three species of Ardeidae documented based on in and-out counting technique from the resting and breeding area of bamboo trees in Gedebage in 2016-2018.

\begin{tabular}{|c|c|c|c|c|}
\hline \multirow[b]{2}{*}{ Study } & \multicolumn{3}{|c|}{ Estimation of population (individuals) } & \multirow[b]{2}{*}{$\begin{array}{c}\text { Total } \\
\text { individuals } *)\end{array}$} \\
\hline & $\begin{array}{c}\text { Little egret } \\
\text { (Bubulcus ibis) }\end{array}$ & $\begin{array}{c}\text { Javan Pond-heron } \\
\text { (Ardeola } \\
\text { speciosa) }\end{array}$ & $\begin{array}{c}\text { Cattle egret } \\
(\text { Egretta garzetta })\end{array}$ & \\
\hline $\begin{array}{l}\text { During partial solar eclipse peri- } \\
\text { od on March } 9,2016^{* *} \text { ) }\end{array}$ & 251 & 190 & 125 & 566 \\
\hline Amdal (2016) & 1004 & 764 & 507 & 2275 \\
\hline Wet sesaon-2017 (Amdal, 2017) & 2176 & 74 & 162 & 2412 \\
\hline Dry season-2017 (Amdal, 2017) & 1312 & 99 & 34 & 1445 \\
\hline $\begin{array}{l}\text { Tim of Dep.Biologi Des '17-Jan } \\
\text { ' } 18\end{array}$ & 1740 & 137 & 275 & 2152 \\
\hline
\end{tabular}

Source: Amdal (2016), Direct Field Observation (2016), and Team of Biology, Unpad (2018). *) Excluding individuals who live in bamboo trees, who are having nests in bamboo trees; **) Only individual who live in bamboo trees and surrounding areas.

Based on Table 1, among the three bird species of Ardeidae in the Rancabayawak, the dominant species is the Cattle Egret (Bubulcus ibis). This result is also in line with research in the Pulau Dua Reserve area, Banten Bay, Java, between the Cattle Egret (Bubulcus ibis), Small Egrets (Egretta garzetta), and Javan Pond-Heron (Ardeola speciosa), the Cattle Egret is the most dominant with fluctuating numbers between 16 to a maximum of 2376 individuals (Noor, 2004). Based on the results of this study it can be inferred that paddy field (sawah) of Rancabayawak, as well as globally sawah in many regions in the world, Jurnal Biodjati 5(2):316-328, November 2020 including Indonesia (Howes et al., 2003), China (Lin et al., 2018), Mediterranean (Fasola \& Ruiz, 1996), America (Acosta et al., 2010), South America (Dias et al., 2014) has been an important habitat for aquatic birds. Although sawah has been very important for the habitat of aquatic birds, its ecosystem in many regions has dramatically changed due to convert to other land use types (Harisa, 2016; Stanton et al., 2018). In our study, however, it can be showed that although land-use changed, the existence of three bird species of Ardeidae tends to be not seriously disrupted. Because there is still an existing resting and 


\section{JURNAL BIDDJATI}

http://journal.uinsgd.ac.id/index.php/biodjati

nesting place in bamboo trees that are guarded by the bamboo owner. Bamboo owners besides protecting their bamboo trees, also protect the three species of birds that commonly using this place for resting and nesting. Besides that, the habitat for looking for feed for the three species of feed birds in the form of the paddy field area also still exists in the Rancabayawak area and its surroundings.

\section{Normal Daily Behavior of the Egrets and Heron}

Three species of Ardeidae Family, Cattle Egret (Bubulcus ibis), Small Egret (Egretta garzetta), and Javan Pond-Heron (Ardeola speciosa) are categorized as aquatic birds, which are ecologically dependent on the presence of wetlands, such as paddy fields (Noor, 2004). Based on their activities, the three species of Ardeidae are active during the daylight (diurnal). Meanwhile, based on the category of resident and migratory birds, the three species of Ardeidae included the resident birds. The resident bird species are birds that breed in Indonesia, while migratory birds are non-breeding birds in Indonesia, but only stop seasonally avoid extreme climate change, such as winter (Howes et al., 2003; Higuchi, 2016; Iskandar, 2017).

On the basis of observations in the Rancabayawak area, the three species of Ardeidae can be distinguished into two main groups, namely groups of breeding and groups of not currently breeding. The activity of the three species of breeding parent egret was more dominant living in the nest forincubating their eggs in the bamboo clumps of the Rancabayawak hamlet. When the eggs have hatched, the parents usually leave and return to their nests after find food for their chicks.

Unlike the group of birds that are breeding, groups of three species of egrets that are not breeding usually have daily routine activi- ties. In the morning, around 05.30-08.00 am the three species of Ardeidae go from the resting place to find food in the paddy field, and in the afternoon they come back to the rest area in the bamboo trees of the Rancabayawak hamlet at 05.00-06.05 pm. This is in line with the opinion of some bird researchers, that tropical bird species, as long as they are not affected by extreme climate, such as winter, their activity influenced by the conditions of sunlight, weather, rainfall, and availability of food in the ecosystem (Iskandar, 2017).

\section{Effect of Partial Solar Eclipse on Three Species of Ardeidae}

Scientifically, a solar eclipse defined as the times when the sun, moon, and earth are in parallel lines that cause sunlight to be blocked by the moon and cannot enter the earth. There are four phases of a total solar eclipse (Lapan, 2016). In the first phase or first contact, when the moon's shadow begins to appear to close the sun's surface, at this time the eclipse begins. In the second phase or the second contact, it occurs when the moon moves until all of the sun's surface covered. At its peak, the sun is really no longer visible because it is covered by the moon. This is what is called the peak of total solar eclipse. After that, the moon's movement has escaped the view of the sun's surface area. Sunlight shines again and the solar eclipse is complete.

Geographically, the Rancabayawak area, Gedebage, Bandung is located around the Summarecon apartment Settlement in the $6^{\circ} 57^{\prime} 30.3^{\prime \prime S}$ and $107^{\circ} 41^{\prime} 36.3^{\prime \prime E}$ (Figure 2). The solar eclipse that occurred in the Rancabayawak area on March 9, 2016, was a partial solar eclipse. In the first phase eclipses occur at $06.19 \mathrm{am}$ and maximum at $07.21 \mathrm{am}$, with a total of about 1 minute 2 seconds (Figure 3 ).

Based on the results of direct observation of the behavior of three species of 


\section{JURNAL BIDDJATI}

http://journal.uinsgd.ac.id/index.php/biodjati

Ardeidae before the partial solar eclipse occurs in the morning (05.15-06.19 am), the sun begins to rise gradually brightly. The sun looks brightly rounded in the east with rather cloudy sky conditions. The behavior of three species of Ardeidae in bamboo clumps can be observed. The chicks of the three species of Ardeidae sound loudly waiting for the feed from their parents. Meanwhile, the parents of some birds go and return to where their chicks in the nest after searching for food in the rice fields of Rancabayawak and its surrounding areas. The three species of Ardeidae that are not breeding, have normal daily behavior. They are solitary, in pairs or in groups flying away from their nest to find food in the rice fields in Rancabayawak and its surroundings.

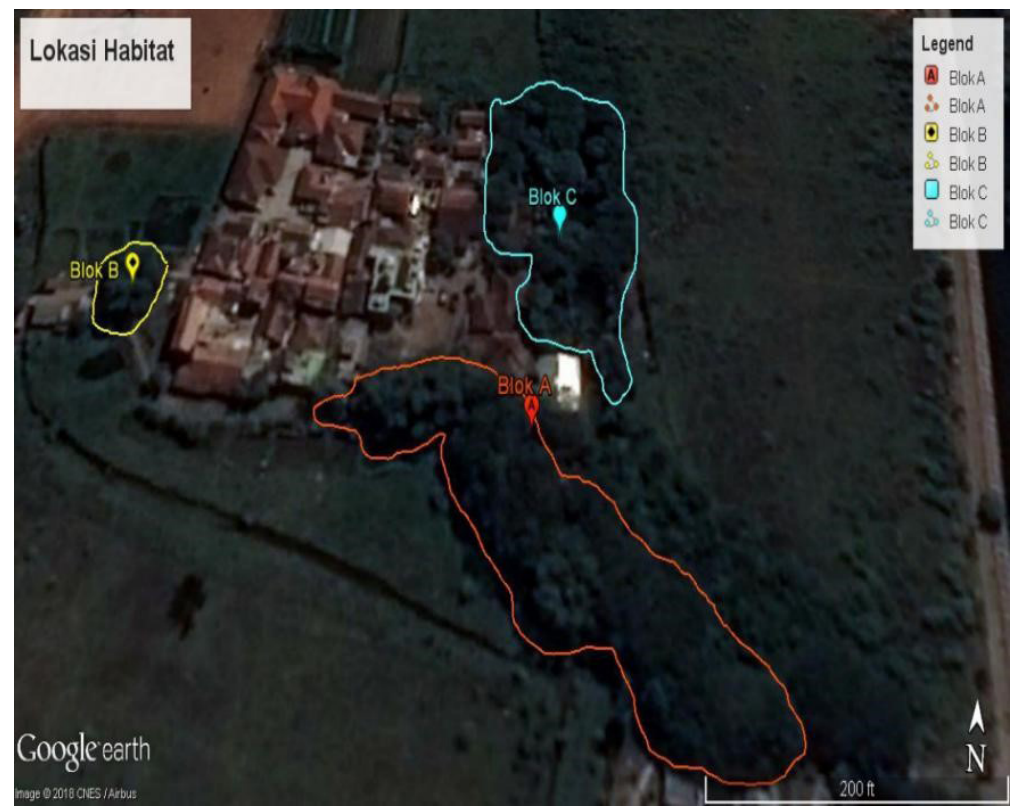

Figure 2. Study area in Rancabayawak, Gedebage, East Bandung, West Java, Indonesia (Block A, B, and C- bamboo trees Department of Biology, UNPAD (2018)

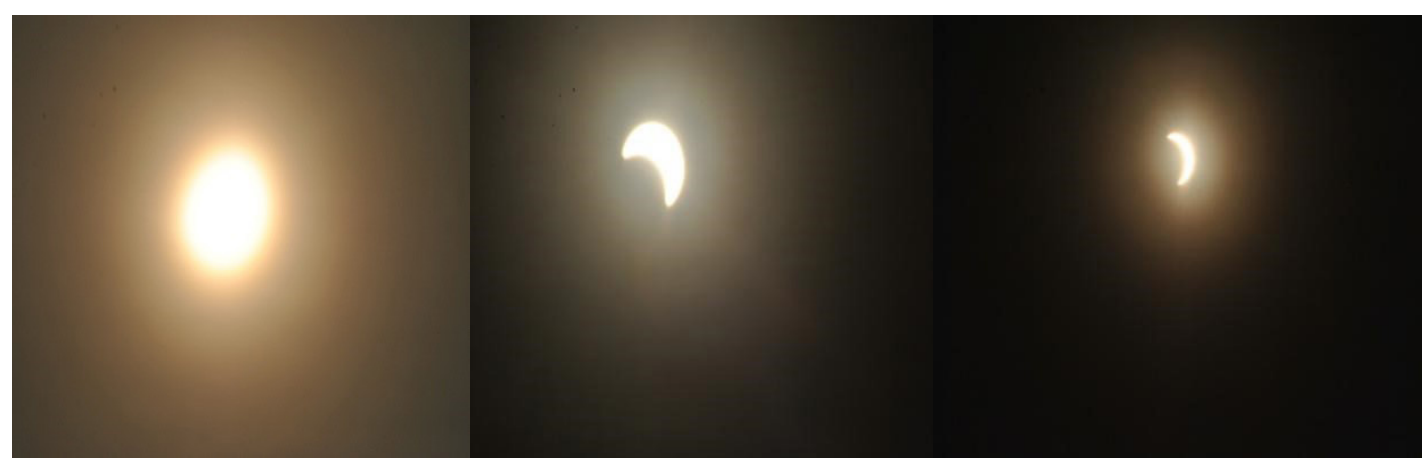

Figure 3. The solar eclipse process in the Rancabayawak area on March 9, 2016. At first, the sun looks round and bright, slowly the edges on the dark left as the moon's shadow began to appear to cover the surface of the sun. Then, slowly, the broader shadow of the moon covers the sun's surface, resulting in bright sun-shaped shapes like a crescent shape. 


\section{JURNAL BIDDJATI}

http://journal.uinsgd.ac.id/index.php/biodjati

In addition, it was also observed that several pairs or small groups of three species of Ardeidae were perched, resting, and sunbathing on the top of bamboo trees. They face east, facing the sun that is shining with a bright round shape. Some effects of the partial solar eclipse on the tree species of Ardeidae can be seen in Table 2 .

Table 2. Activities of the observed the Ardeidae bird at normal conditions and during the partial solar eclipse on bamboo trees and surrounding area in Gedebage in March 9, 2019.

\begin{tabular}{|c|c|c|c|}
\hline \multirow{2}{*}{ Activities } & \multicolumn{3}{|c|}{ The Partial Solar Eclipse } \\
\hline & Before & During & After \\
\hline $\begin{array}{l}\text { Sound of chicks in the } \\
\text { nest of bamboo trees }\end{array}$ & $\begin{array}{l}\text { Heard a loud voice be- } \\
\text { cause they were hungry } \\
\text { for food from the mother }\end{array}$ & $\begin{array}{l}\text { The sound of the chicks } \\
\text { was not heard loudly } \\
\text { because it might be night } \\
\text { time }\end{array}$ & $\begin{array}{l}\text { Heard a loud voice be- } \\
\text { cause they were hungry } \\
\text { for food from the mother }\end{array}$ \\
\hline Sunbathing & $\begin{array}{l}\text { Some individual birds } \\
\text { were perched on top of } \\
\text { bamboo trees for sunbath- } \\
\text { ing in the morning sun } \\
\text { shine facing east direction }\end{array}$ & $\begin{array}{l}\text { Several individual birds } \\
\text { were perched on top of } \\
\text { bamboo trees for sunbath- } \\
\text { ing in the morning sun } \\
\text { shine turning toward the } \\
\text { west }\end{array}$ & $\begin{array}{l}\text { Several individual birds } \\
\text { were perched on top of } \\
\text { bamboo for sunbathing } \\
\text { turning back to the west }\end{array}$ \\
\hline Preening the feather & $\begin{array}{l}\text { Some individual birds } \\
\text { actively involved in } \\
\text { preening their feathers }\end{array}$ & $\begin{array}{l}\text { Some individual birds } \\
\text { stopped involve in preen- } \\
\text { ing their feather }\end{array}$ & $\begin{array}{l}\text { Several individual birds } \\
\text { reactively involved in } \\
\text { preening their feathers }\end{array}$ \\
\hline Flying & $\begin{array}{l}\text { Some individual birds } \\
\text { were flying go out from } \\
\text { the nest of bamboo trees }\end{array}$ & $\begin{array}{l}\text { Some individual birds } \\
\text { were flying go back to the } \\
\text { nest of bamboo trees that } \\
\text { may be assumed it has } \\
\text { already late afternoon due } \\
\text { to dark of sun shine }\end{array}$ & $\begin{array}{l}\text { Some individual birds } \\
\text { were flying go out from } \\
\text { the nest of bamboo trees }\end{array}$ \\
\hline
\end{tabular}

At 06.19-07.21 am, there was a partial solar eclipse process in the Rancabayawak area. At first, the sun looks round and bright, slowly the dark on the edges left as the moon's shadow began to appear to cover the surface of the sun. Then, slowly, the broader shadow of the moon covers the sun's surface, resulting in bright sun-shaped shapes like a crescent shape (Figure 3). At its peak, the sun really looks bright in the form of a thin crescent, not total darkness as the solar eclipse that occurs was a partial eclipse which around $88 \%$. We did not measure temperature changes before and after the partial solar eclipse event, however, based on the cases in other areas, particularly during full solar eclipse time, temperature was recodIskandar \& Iskandar ed decrease gradually to between $1.3^{\circ} \mathrm{C}$ and $4.05^{\circ} \mathrm{C}$ and then rise over time (Asmoro et al., 2016; Wiantoro et al., 2019).

During the partial solar eclipse (06.19$07.21 \mathrm{am}$ ) in the Rancabayawak area, it could be observed that the crowded sounds of chicks of three species of Ardeidae in the nest was temporarily stopped (Figure 4). This was caused by the rather dark sunlight, and it was estimated that the birds thought it was late afternoon, usually, the parents stopped feeding. At the time of the partial solar eclipse, several groups of individuals to three species of Ardeidae can be observed, coming from the east, south and north, and perching to rest in the bamboo trees. Several groups of the tree 


\section{JURNAL BIDDJATI}

http://journal.uinsgd.ac.id/index.php/biodjati

species of Ardeidae have come back to their rest area of the bamboo trees that normally done in the late afternoon. Since at the time the sun was dark due to a partial solar eclipse. In addition, several groups of three species of birds that usually seen perched, resting, and sunbathing facing the east, when a partial solar eclipse occurred, they turned their backs to the sun-facing west.

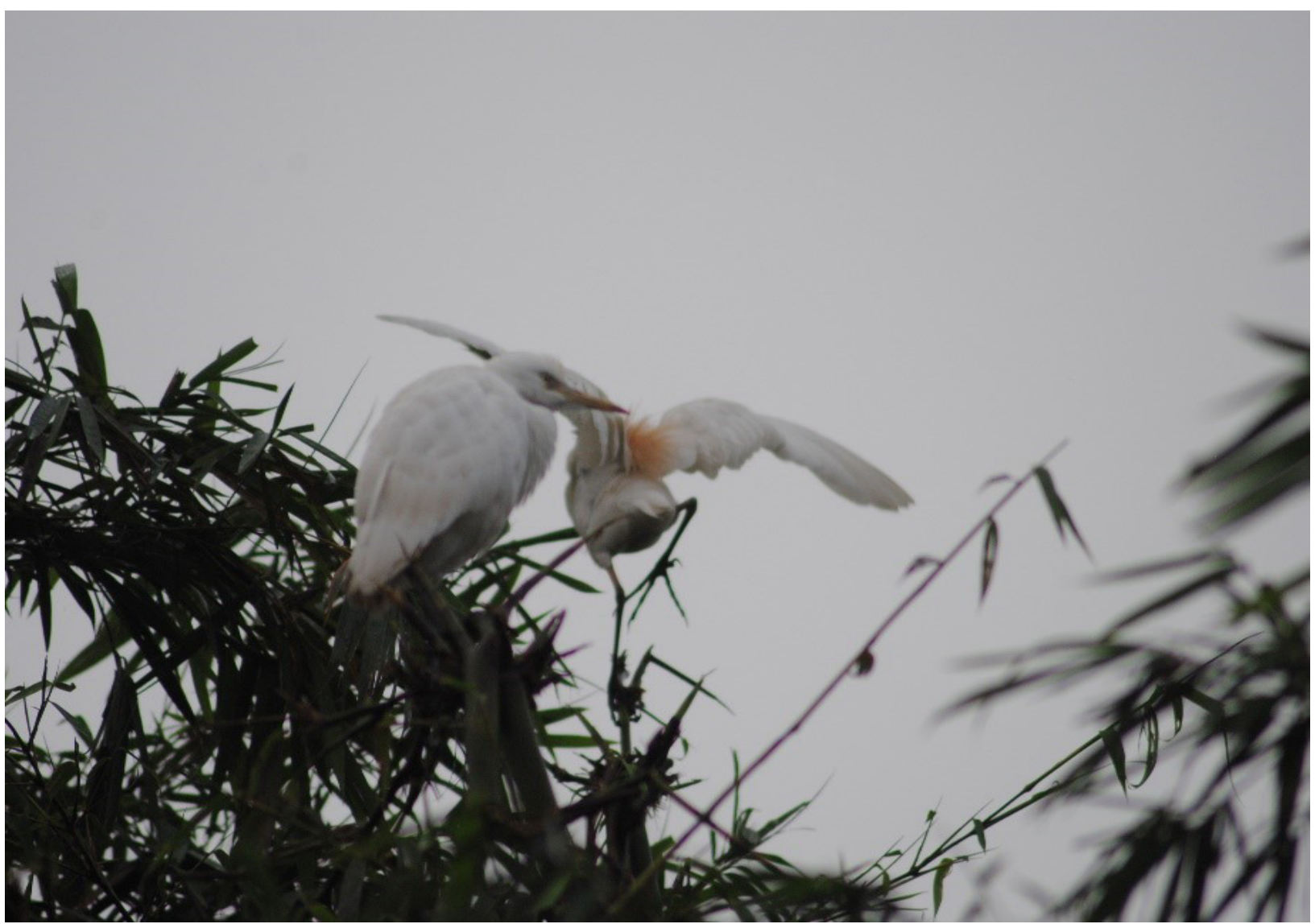

Figure 4. During the solar eclipse (06.19-07.21 am) on March 9, 2016 in the Rancabayawak area, it could be observed that the crowded sounds of chicks of three species of egret that are in the nest temporary stopped because it was dark and maybe it was assumed as late afternoon.

When the partial solar eclipse ends (after $07.21 \mathrm{am}$ ), the crescent-shaped sunlight gradually enlarges, forming a round and bright shape. It can be seen the behavior of three species of Ardeidae showed a tendency returned to normal behavior. For example, when a partial solar eclipse ends, the chicks of tree species of Ardeidae in the nests of the bamboo trees began crowded sounds as wait for their parent to give foods. In addition, after the partial solar eclipse ended and the Jurnal Biodjati 5(2):316-328, November 2020 sun's light started to get brighter, polarity or small group several individuals of three species of Ardeidae moved from perching the behind bamboo leaves moved on the tops of bamboo clumps for sunbathing.

Based on this study, it can be concluded that the presence of a partial solar eclipse has affected the behavior changes from the three species of Ardeidae that are usually resting, dry, and nesting in bamboo clumps on the edge Rancabayawak hamlet, Gedebage, Bandung. 


\section{JURNAL BIDDJATI}

http://journal.uinsgd.ac.id/index.php/biodjati

The results of this study, also strengthened from sharing reports in various regions in Indonesia, due to the total eclipse on March 9, 2016, the changes in animal behavior both in nature and in pet cages were observed (Dody, 2016; Kamri, 2016; LIPI, 2016a,b,c,d; Oktaviano, 2016; Shanida, et al., 2016; Sulistiyono, 2016; Yusmanto, 2016; Moro et al., 2017). For example, the activity of proboscis monkey (Nasalis laravatus) in mangrove forests, Kariangau, East Kalimantan, stopped significantly during the total solar eclipse, and these animals return after the total solar eclipse (Shanida et al., 2016).

Likewise, from other reports, such as observations at the Ragunan Zoo, Jakarta, at the time of the total solar eclipse showed that many animals were not as normal as their daily habits. For example, the species of birds that usually did many activities in the morning, they were quiet, not actively moving as usual. Because during the total solar eclipse the sunlight was dark, many species of birds assumed that it is still night. The results of other observations during the total solar eclipse, in the forest area of Mercu Suar, Tanjung Berikat. Batu Beriga village, Central Bangka Regency, at 07.22 am showed that the bird species in the area stopped their activities. Then, the chirping of the species of birds was heard again in the end of the total solar eclipse. The species of canary that kept in the cage at Tanjungpandan, Belitung, the condition of the overcast sun due to a total solar eclipse at 07.17 a.m., resulted in fearful behavior of canary. In addition, a pet canary owned by a resident in Lesung Batang, Tanjungpandan, suddenly did not want to sing. Similarly, the canary who was the first winner of the bird contest song showed behavior change dramatically. The bird that had been diligently singing. When the sun was dark due to a total solar eclipse, it behaved like fear and silence did not want to sing. Meanwhile, small mammal species, including squirrel that before a full solar eclipse was seen chasing, did not appear active during full solar eclipse (Dody, 2016; Yusmanto, 2016). According to Yusmanto (2016), strange behavior also affected other species of songbirds, such as lovebird, kacer, hummingbirds, and murai who were busy chirping. But due to the total solar eclipse all birds became silent. In addition, due to a total solar eclipse, domestic chickens entered the cage. According to LIPI (2016a), who conducted research in South Sulawesi mentioned that before the total eclipse some animal voices were herd. However, once the total solar eclipse and dark for 3 minutes, many animals become silent. For example, the king fisher's bird was previously active, but after the sun was cloudy due to total solar eclipse, the bird was no longer active and was looking for a place to hide.

Although some observations and studies on the impacts of the total solar eclipse on various bird behaviors have been undertaken in different regions of Indonesia, our study is different from the previous studies that was mainly focused on wild birds, birds kept in the home cages, or bird in the cages of zoological gardens. Bird species observed were dissimilar as our study were focused on water birds of Ardeidae family. In addition, our study was carried out to understand that the birds' reaction to the partial solar eclipse are strictly individuals (Nankinov et al. 2001). Three species of Ardeidae family, namely Cattle Egret (Bubulcus ibis), Small Egret (Egretta garzeta) and Javan Pond-Heron (Ardeola speciosa) was observed in different age, particularly chick and mature individuals that showed different behavior in respond to the partial solar eclipse.

Based on the results of this study, our research results are considered to be important 


\section{JURNAL BIDDJATI}

http://journal.uinsgd.ac.id/index.php/biodjati

in developing our knowledge regarding the impacts of the partial solar eclipse on water birds of Ardeidae family in different species and different ages, namely chick and mature individuals in the roosting and nesting place of bamboo trees.

\section{ACKNOWLEDGEMENTS}

We would like to thank the Chairperson of the RT and the Rancabayawak community for providing information and assisting in the smooth running of this research. The socialization and publication of this article in a journal was funded by ALG (Academic Leadership Program) Mr. Johan Iskandar. Therefore, we thank the Unpad Rector, who supports and funds the ALG program.

\section{REFERENCES}

Acosta, M., Mugica, L., Blanco, D., LópezLanús, B., Dias, R. A., Doodnath, L. W. \& Hurtado, J. (2010). Birds of Rice Fields in the Americas. Waterbirds, 33(1), 105-122.

Amdal. (2016). Rencana Pembangunan Perumahan dan Areal Komersial Summarecon Bandung. Bandung: PT. Mahkota Permata Perdana.

Ardi, N. D., Gandini, R, Asmoro, C. P., Wijaya, A. F. C., Tayubi, Y. R. \& Mujtahiddin, I. (2017). Analisis Sprektral Suhu dan Tekanan Udara Selama Gerhana Matahari Total 2016 di Bangka Tengah. Prosiding Seminar Nasional Sains Antartika. Pusat Sains Antaratika Lapan, Bandung.

Asmoro, C. P., Wijaya, A. F. C., Ardi, N. D., Abdurrohman, A., Utama J. A., Sutiadi, A., Hikmat, Ramalis, T. A. \& Suryadi, B. (2016). The Assembled Solar Eclipse Package (ASEP) in Bangka Indonesia
During the Total Solar Eclipse on March 9, 2016. Journal of Physics: Conference Series, 771, pp.1-4.

Bibby, C. J., Burgess, N. D. \& Hill, D. A. (1992). Bird Censuses Techniques. London: Academic Press Limited.

Department of Biology. (2018). Inventarisasi dan Pengelolaan Tiga Jenis Burung Air (Burung Blekok, Burung Kuntul Kecil) di Kawasan Rancabayawak, Kota Bandung. Report research, Department of Biology, UNPAD.

Burton, R. (1985). Bird Behaviour. London: Granada Publishing Limited.

Dias, R. A, Blanco, D. E., Goijman, A. P. \& Zaccagnini, M. E. (2014). Density, Habitat Use, and Opportunities for Conservation of Shorebirds in Rice Fields in Southeastern South America. The Condor: Ornithological Applications, 116(3), 384-393.

Dody. (2016). Saat Gerhana Matahari, Burung Berhenti Berkicau. Retrieved from http://bangka.tribunnews. com/2016/03/10/saat-gerhana-matahari-burung-berhenti-berkicau.

Fasola, M. \& Ruiz, X. (1996). The Value of Rice Fields as Substitutes for Natural Wetlands for Water Birds in the Mediterranean Region. Colonial Waterbirds, 19(1), 122-128.

Harisa, M. N. (2016). Assessment of Status, Diversity, and Threat of Wetland Birds of Bathi Lake, Doddabati Village, Davanagere District, Karnataka, India. Journal of Entomology and Zoology Studies, 4(4), 586-590.

Higuchi, H. (2016). Rekam Jejak Perjalanan Migrasi Burung Menggunakan Teknologi Satelite-Tracking. Diterjemahkan oleh Syartinilia. Bogor: Penerbit IPB Press.

Howes, J., Bakewell, D. \& Noor, Y. R. (2003). 


\section{JURNAL BIDDJATI}

http://journal.uinsgd.ac.id/index.php/biodjati

Panduan Studi Burung Pantai. Bogor: Wetlands International-Indonesia Programme.

Iskandar, J. (2017). Ornitologi dan Etnoornitologi. Yogyakarta: Plantaxia.

Iskandar, J. (2018). Etnobiologi, Ethnoekologi dan Pembangunan Berkelanjutan. Yogyakarta: Plantaxia.

Kamri. (2016). Gerhana Bikin Burung Juara Kontes Ini Mendadak Jadi Pendiam Seperti Stres. Retrieved from http:// belitung.tribunnews.com/2016/03/09/ gerhana-bikin-burung-juara-kontes-ini-mendadak-jadi-pendiam-seperti-stres.

Kosasih, E. (2020). Perubahan Penggunaan Lahan Sawah dan Dampaknya Tehadap Burung Air di Kecamatan Gedebage, Kota Bandung. Tesis. Magister Program of Environmental Science, UNPAD.

Lapan. (2016). The-Eclipse-Gerhana Matahari Total: Catatan Peristiwa 9 Maret 2016. Jakarta: Lembaga Penerbangan dan Antariksa.

Lin, W., Cen, J., Xu, D., Du, S. \& Gao, J. (2018). Wetland Landscape Pattern Changes Over A Period Development (1985-2015) In The Zhoushan Islands of Zhejiang Province, China. Estuarine, Coastal dan Shelf Science, 213, 148159.

LIPI. (2016a). Perilaku Satwa Saat Gerhana, Begini Hasil Penelitian LIPI. Retrieved from https://tekno.tempo.co/ $\mathrm{read} / 752098 /$ perilaku-satwa-saat-gerhana-begini-hasil-penelitian-lipi/ full\&view $=$ ok.

LIPI. (2016b). Perilaku Unik Satwa Saat Gerhana Matahari. Retrieved from http:// lipi.go.id/lipimedia/perilaku-unik-satwa- saat-gerhana-matahari/15272.

LIPI. (2016c). Begini Respons Reptil Saat Gerhana Matahari. Retrieved from http://lipi.go.id/lipimedia/begini-respons-reptil-saat-gerhana-matahari/15251.

LIPI. (2016d). LIPI Temukan Perilaku Unik Satwa Saat Gerhana Matahari. Retrieved from http://lipi.go.id/lipimedia/ single/lipi-temukan-perilaku-unik-satwa-saat-gerhana-matahari/15244.

MacKinnon, J., Phillips, K. \& Balen, B. V. (1992). Burung-Burung di Sumatera, Jawa, Bali dan Kalimantan. Bogor: LIPI/Bird Life.

Moro, H. K. E. P., Hanifah, N., Tanzilla, R. \& Lestarningsih. (2017). Perilaku Reptilia Ketika Gerhana Matahari Parsial di Pasty Yogyakarta. Biotropic Journal of Tropical, 1(2), 37-40.

Nandiyanto, A. B. D., Rusli, A, Purnamasari, A., Abdullah, A. G. A. \& Riza, L. S. (2017). Behavior of Photovoltaic during the Partial Solar Eclipse in Bandung. IOP Conf.Series: Material Science and Engineering, 180, 1-7.

Nankinov, D., Dalakcheiva, S., Nikolov, B., Shurullinkov, P., Popov, K., Kirilov, S., Zareva, K., Borisov, B., Stojanov, G., Nankinov, N., Minchev, N., Kjichukov, D., Nikolov, I., Stanchev, R. \& Gonchev, E. (2001). Studying the Behaviour of Birds During the Solar Eclipse on August 11, 1999. Russian Ornithological Journal, 142, 355-369.

Noor Y. S. (2004). Paparan Nilai Penting Cagar Alam Pulau Dua, Teluk Banten Sebagai Kawasan Berbiak Burung Air Disertai Panduan Pengenalan Jenis Burung Air. Bogor: Wetlands International Indonesia Program.

Oktaviano, L. (2016). Tingkah Laku Binatang di Ragunan Berubah saat Gerhana Matahari. Retrieved from http:// wartakota.tribunnews.com/2016/03/09/ tingkah-laku-binatang-di-ragu- 


\section{JURNAL BIDDJATI}

http://journal.uinsgd.ac.id/index.php/biodjati

nan-berubah-saat-gerhana-matahari.

Ozbey, O, Aysondu, M. H., Ozer, H. \& Simsek, O. G. (2004). The effects of a solar eclipse on Animals Behavior. Turkish Journal Veterinary and Animal Science, 28(1), 55-61.

Pettingill, O. S.(1970). Ornithology in Laboratory and Field. Minnepolis, Minn: Burgess Publishing Company. Forth Edition.

Ritson R., Ranglack, D. H. \& Bickford, N. (2018). Comparing Social Media Observations of Animals During a Solar Eclipse to Published Research. Animals, 9(2), 1-12.

Shanida S, Lestari, T. H. \& Partasasmita, R. (2016). The Effect of Total Solar Eclipse on the Daily Activities of Nasalis larvatus (Wurmb) in Mangrove Center, Karingau, East Kalimantan. J.Phys. Conf. Ser. 771, 1-4.
Sodhi N. S., Sekerciouglu C. H., Balow, J. \& Robinson, S. K. (2011). Conservation of Tropical Birds. Chichester, Sussex: Willey-Blackwell.

Sulistiyono S. T. (2016). Unggas dan Primata Bertingkah Aneh Saat Gerhana Matahari. Retrieved from http://www.tribunnews.com/metropolitan/2016/03/09/ ung gas - d a n - primata-berting kah-aneh-saat-gerhana-matahari.

Yusmanto, E. (2016). Gerhana Terjadi, Burung-Burung Menghilang Sejenak. Retrieved from http://belitung.tribunnews. com/2016/03/09/gerhana-terjadi-burung-burung-menghilang-sejenak.

Wiantoro S, Narakusumo, R. P., Sulstiyadi, E., Hamidy, A. \& Fachry, F. (2019). Effect of Solar Eclipse of March 9, 2016 on the Animal Behaviour. Journal of Tropical Biology and Conservation, 16, 137-149. 